Retraction

\title{
Retracted: Hyperglycemia Induces Toll-Like Receptor-2 and -4 Expression and Activity in Human Microvascular Retinal Endothelial Cells: Implications for Diabetic Retinopathy
}

\author{
Journal of Diabetes Research \\ Received 24 September 2020; Accepted 24 September 2020; Published 31 October 2020 \\ Copyright $\odot 2020$ Journal of Diabetes Research. This is an open access article distributed under the Creative Commons Attribution \\ License, which permits unrestricted use, distribution, and reproduction in any medium, provided the original work is \\ properly cited.
}

Journal of Diabetes Research has retracted the article titled "Hyperglycemia Induces Toll-Like Receptor-2 and -4 Expression and Activity in Human Microvascular Retinal Endothelial Cells: Implications for Diabetic Retinopathy" [1] due to concerns identified with Figures 1 and 2.

Following the publication of an erratum to correct an image duplication in Figure 2 [2], concerns have been identified in the original publication, and in the revised figure provided by the authors. Our concerns are as follows:

Figure 1(a)

(i) GADPH bands C and 15 are the same as bands 25 and $\mathrm{M}$ (horizontally flipped).

(ii) In the TLR4 bands, there is an undeclared gel splice between the $\mathrm{C}$ and 15 bands

Figure 1(b)

(i) There is an undeclared gel splice between the 25 and M lanes of TLR4 which is not consistent with the loading control

Figure 2(c)

(i) There is an undeclared gel splice between the $\mathrm{C}$ and 15 lanes of TRIF and IRF3

(ii) There is an undeclared gel splice between the 25 and $M$ lanes of TRIF and IRF3

(iii) These gel splices are not consistent with the loading control
With the agreement with the Chief Editor, this article is therefore being retracted due to the above concerns.

\section{References}

[1] U. Rajamani and I. Jialal, "Hyperglycemia Induces Toll-Like Receptor-2 and -4 Expression and Activity in Human Microvascular Retinal Endothelial Cells: Implications for Diabetic Retinopathy," Journal of Diabetes Research, vol. 2014, Article ID 790902, 15 pages, 2014.

[2] U. Rajamani and I. Jialal, "Erratum to "Hyperglycemia Induces Toll-Like Receptor-2 and -4 Expression and Activity in Human Microvascular Retinal Endothelial Cells: Implications for Diabetic Retinopathy"," Journal of Diabetes Research, vol. 2016, Article ID 8976945, 2 pages, 2016. 